\title{
Pengaruh Perputaran Modal Kerja, Operating Leverage dan Financial Leverage terhadap Profitabilitas Perusahaan Sektor Retail di Bursa Efek Indonesia
}

\author{
The Influence of Working Capital Turnover, Operating \\ Leverage and Financial Leverage on Profitability of Retail \\ Sector Firms in Indonesia Stock Exchange
}

\author{
Muhammad Fuad19*, Oyami Sara'2) \& Muhammad Nur Daud ${ }^{3)}$ \\ 1,2,3)Prodi Manajemen, Fakultas Ekonomi, Universitas Samudra, Indonesia \\ *Corresponding Email: muhammadfuad@unsam.ac.id
}

\begin{abstract}
Abstrak
Penelitian ini bertujuan untuk menganalisis pengaruh antara perputaran modal kerja, operating leverage dan financial leverage terhadap profitabilitas. Obyek penelitian adalh tiga belas perusahaan sektor retail terdaftar di Bursa Efek Indonesia (BEI) yang dipilih berdasarkan kriteria tertetu. Data sekunder berupa laporan keuangan dari masing-masing perusahaan dalam periode 2013 sampai 2017, dan dianalisis menggunakan metode regresi linier berganda. Hasil-hasil yang diperoleh menyatakan bahwa masingmasing perputaran modal kerja, operating leverage dan financial leverage memiliki pengaruh yang positif pada profitabilitas perusahaan sektor retail di BEI. Namun demikian, hasil uji parsial membuktikan bahwa hanya financial leverage yang memiliki pengaruh signifikan terhadap profitabilitas; sementara perputaran modal kerja dan operating leverage terbukti berpengaruh tidak signifikan. Secara simultan, ketiga variabel independen yang dianalisis memiliki pengaruh yang signifikan terhadap profitabilitas perusahaan sektor retail di BEI.
\end{abstract}

Kata Kunci: Perputaran Modal Kerja, Operating Leverage, Financial Leverage, Profitabilitas

\begin{abstract}
This study aims to analyze the influence of working capital turnover, operating leverage and financial leverage on profitability. The research object is thirteen retail sector companies listed on the Indonesia Stock Exchange (IDX) which are selected based on certain criteria. Secondary data are in the form of financial statements from each company in the period 2013 to 2017, and analyzed using multiple linear regression methods. The results obtained state that each working capital turnover, operating leverage and financial leverage have a positive influence on the profitability of retail sector companies on the IDX. However, the results of the partial test prove that only financial leverage has a significant influence on profitability; while working capital turnover and operating leverage proved to be insignificant. Simultaneously, the three independent variables analyzed have a significant influence on the profitability of retail sector companies on the IDX.
\end{abstract}

Keywords: Working Capital Turnover, Operating Leverage, Financial Leverage, Profitability.

How to Cite: Fuad, M., Sara, O. \& Daud, M.N. (2019). Pengaruh Perputaran Modal Kerja, Operating Leverage dan Financial Leverage terhadap Profitabilitas Perusahaan Sektor Retail di Bursa Efek Indonesia. Jurnal Konsep Bisnis dan Manajemen. 5 (2): 131-145 


\section{PENDAHULUAN}

Profitabilitas merupakan salah satu aspek keuangan yang berperan penting dalam proses pengambilan keputusan investasi oleh para investor maupun proses terciptanya arah sentimen pasar atas suatu perusahaan yang terdaftar dalam Bursa Efek Indonesia (BEI). Profitabilitas menunjukkan derajat kemampuan perusahaan go publik untuk menghasilkan profit atau laba bersih melalui penggunaan semua asset yang dimilikinya (Kasmir, 2015; Brealey et al., 2011). Apabila perusahaan mampu secara berkesinambungan mempertinggi nilai profitabilitasnya maka menunjukkan bahwa perusahaan yang bersangkutan semakin mampu mengelola semua asset yang dimilikinya dengan baik sehingga mampu mencapai nilai profit yang terus meningkat (Brigham \& Daves, 2016; Gumanti, 2017). Para investor yang mengobservasi kondisi tersebut tentu menilai bahwa perusahaan itu memiliki potensi keberlanjutan yang besar dan merupakan pilihan investasi yang menarik dan menguntungkan.

Dengan demikian, kemampuan perusahaan mempertinggi tingkat profitabilitasnya akan mendorong para investor untuk bersedia menginvestasikan dananya kepada perusahaan yang bersangkutan, dan selanjutnya mendukung kemampuan perusahaan untuk melakukan berbagai ekspansi menguntungkan di masa datang sehingga menjamin keberlanjutan aktivitas bisnisnya.

Obyek dari studi ini adalah perusahaan sektor retail yang terdaftar di Bursa Efek Indonesia (BEI). Perusahaan sektor retail didefnisikan sebagai perusahaan yang memiliki aktivitas bisnis memasarkan produk-produk barang ataupun jasa kepada kelompok konsumen akhir yang menggunakannya untuk memenuhi keperluan rumah tangga atau pribadi, dan bukan untuk dijual kembali ataupun dproses lebih lanjut sebagai bahan baku bagi produk yang lain (Alma, 2013; Berman \& Evans, 2010; Sopiah \& Syihabudin, 2008)

Alasan memilih obyek perusahaan ini adalah adanya fenomena menarik yang terjadi saat ini yaitu banyaknya perusahaan sektor retail yang menutup gerai-gerai belanja miliknya. Sugianto (2017) pada media Detikcom laman detikFinance mencatat data selama tahun 2017 sejumlah jajaran bisnis sektor retail yang menutup sejumlah gerainya, misalnya PT. Matahari Department Store Tbk (LPPF) menutup beberapa gerai besarnya di akhir September, ataupun PT. Mitra Adiperkasa Tbk (MAPI) menutup seluruh gerai Lotus 
miliknya yang tersebar di lima lokasi pada bulan Oktober.

Selain itu, Wakil Ketua Umum Aprindo (Asosiasi Pengusaha Retail Indonesia) Tutum Rahanta dalam suatu event di Jakarta pada tanggal 16 Januari 2019 menyatakan bahwa pada tahun 2018 terjadi penutupan gerai sebanyak 400 unit, diantaranya dialami PT. Hero Supermarket Tbk (HERO) yang menutup 26 gerainya dan melakukan pemutusan hubungan kerja (PHK) terhadap 532 karyawannya (Reily, 2019).

Beberapa alasan diungkapkan untuk menjelaskan fenomena penutupan geraigerai perusahaan sektor retail tersebut. Selain adanya penurunan daya beli dan minat konsumsi dari masyarakat karena situasi ekonomi secara domestik maupun global yang sedang lesu sehingga mengakibatkan turunnya nilai penjualan dari perusahaan sektor retail, alasan utama lain yang dinilai perlu dicermati lebih mendalam adalah mulai maraknya $e$ commerce toko online yang menjadi pesaing utama dari penjualan offline pada gerai fisik (Reily, 2019; Zaking, 2019).

Toko online memudahkan para konsumen untuk dapat membeli barangbarang yang dibutuhkan maupun yang diinginkannya tanpa harus keluar rumah untuk mengurang gerai fisik. Melalui toko online, para konsumen juga bisa bebas memilih produk-produk impor tanpa perlu bersusah payah mengurus dokumen penerimaannya di di dalam negeri (Hamdani, 2019; Sugianto, 2017). Perkembangan retail daring itu dinilai akan merubah pola konsumsi maupun tren belanja di dalam masyarakat, dan selanjutnya akan mempengaruhi keberadaan gerai fisik dari perusahaan retail. Fenomena tersebut dapat mempengaruhi derajat profitabilitas yang dimiliki perusahaan retail yang bersangkutan, dan apabila tidak segera direspon maka bisa menyebabkan terjadinya penurunan nilai penjualan bersih ataupun nilai laba bersih setelah pajak dibandingkan total asset yang digunakan untuk menghasilkan penjualan atau laba bersih tersebut.

Memperhitungkan pentingnya peran profitabilitas demi mampu bersaing di pasar maupun mampu mempertahankan keberlangsungan usahanya, maka pihak manajemen dari perusahaan sektor retail khususnya yang terdaftar di BEI perlu menetapkan strategi bisnis yang tepat untuk mampu meningkatkan kemampuan profitabilitasnya tersebut. Untuk menetapkan strategi yang sesuai, perlu diidentifikasi dahulu arah dan tingkat signifikansi dari pengaruh beberapa 
Muhammad Fuad, Oyami Sara, \& Muhammad Nur Daud, Pengaruh Perputaran Modal Kerja, Operating Leverage dan Financial Leverage terhadap Profitabilitas Perusahaan Sektor Retail di Bursa Efek Indonesia

variabel yang diduga terhadap pergerakan profitabilitas usaha. Dalam studi ini, tiga variabel independen yang dianalisis pengaruhnya terhadap profitabilitas perusahaan sektor retail, yaitu perputaran modal kerja, operating leverage dan financial leverage.

Modal kerja (working capital) bagi seorang manajer keuangan adalah total asset lancar yang dimiliki dan digunakan dalam aktivitas operasional bisnis oleh perusahaannya, seperti kas, piutang dan persediaan (Jumingan, 2011; Brigham \& Daves, 2016). Kinerja pengelolaan modal kerja yang baik bisa diukur dari tingkat perputaran modal kerja, yang menunjukkan adanya efisiensi sejak uang tunai diinvestasikan ke dalam bentukbentuk modal kerja sampai saat kembali menjadi uang tunai kembali (Kasmir, 2015; Husnan \& Pudjiastuti, 2012). Secara konsep, semakin cepat perputaran modal kerja maka semakin efisien perusahaan menggunakan modal kerja tersebut, dan pada akhirnya profitabilitas mengalami peningkatan (Pangestuti \& Oetomo, 2016). Secara empiris, studi Pais dan Gama (2015) bahwa semakin agresif manajemen modal kerja yang dilakukan maka akan meningkatkan profitabilitas yang diraih perusahaan bersangkutan. Hasil-hasil studi yang diperoleh Şamiloğlu dan Akgűn (2016) maupun Putri dan Sudiartha (2015) juga menemukan perputaran modal kerja berpengaruh positif dan signifikan terhadap profitabilitas. Namun demikian, Kusumo dan Darmawan menemukan hasil studi bahwa perputaran modal kerja tidak berpengaruh signifikan terhadap profitabilitas. Dengan demikian, belum diperoleh konsensus berkenaan dengan pengaruh dari perputaran modal kerja terhadap profitabilitas, sehingga menarik untuk ditelaah lebih lanjut melalui studi saat ini.

Leverage

menggambarkan kemampuan perusahaan karena menggunakan bentuk-bentuk sumber dana yang memiliki biaya atau beban tetap (seperti utang ataupun saham preferen) dalam upaya meningkatkan keuntungan perusahaan dan memaksimalkan kekayaan pemilik atau pemegang saham perusahaan (Fahmi, 2015; Sartono, 2008). Analisis leverage dapat dbedakan menjadi dua tipe, yaitu operating leverage dan financial leverage. Hubungan dari masing-masing tipe leverage tersebut dijelaskan sebagai berikut.

Operating leverage menunjukkan kemampuan perusahaan dalam menggunakan biaya-biaya operasional yang bersifat tetap (fixed operating costs) di dalam aktivitas operasionalnya untuk menghasilkan penjualan serta laba operasional (EBIT) yang meningkat 
(Syamsuddin, 2016; Adongo, 2012). yang akan diterima pemilik atau pemegang Operating leverage diukur menggunakan saham perusahaan (Sartono, 2008; degree of operating leverage (DOL) yang Brigham \& Daves, 2016; Adongo, 2012). diperoleh dengan memperbandingkan Financial leverage dalam studi ini diukur antara persentase perubahan EBIT menggunakan degree of financial leverage terhadap persentase perubahan penjualan (DFL), yaitu membandingkan antara (Syamsuddin, 2016; Sen \& Ranjan, 2018). persentas perubahan Earning per Share Dalam hubungannya dengan profitabilitas perusahaan, sejumlah studi menemukan hasil yang beragam. Hasil studi milik Chen et al. (2017) serta Patel (2014) menemukan bahwa operating leverage berpengaruh secara positif dan signifikan terhadap profitabilitas. Sebaliknya, studi milik Lestari dan Nuzula (2017) menemukan operating leverage secara parsial berpengaruh secara negatif dan signifikan terhadap profitabilitas. Hasil studi yang lain milik Pangestuti dan Oetomo (2016) serta Sen dan Ranjan (2018) menemukan bahwa operating leverage berpengaruh secara tidak signifikan terhadap profitabilitas. Pelaksanaan studi saat ini berupaya mengkonfirmasi keragaman hasil terdahulu tersebut mengenai pengaruh operating leverage terhadap profitabilitas.

Financial leverage menunjukkan kemampuan perusahaan dalam menggunakan sumber-sumber pendanaan yang memiliki biaya tetap di dalam aktivitas bisnisnya untuk menghasilkan peningkatan laba per lembar saham (EPS) (EPS) dengan persentase perubahan EBIT (Halim, 2015; Syamsuddin, 2016; Sen \& Renjen, 2018). Studi-studi terdahulu belum menemukan kesepakatan mengenai sifat pengaruh dari financial leverage terhadap profitabilitas. Studi milik Ahmad et al. (2015) serta Patel (2014) menemukan bahwa financial leverage berpengaruh secara negatif dan signifikan terhadap profitabilitas; sebaiknya Adongo (2012) menemukan bahwa financial leverage berpengaruh secara positif dan signifikan terhadap profitabilitas. Sementara itu, hasil-hasil studi milik Lestari dan Nuzula (2017), Avistasari et al. (2016) serta Sen dan Ranjan (2018), menemukan bahwa financial leverage berpengaruh secara tidak signifikan terhadap profitabilitas. Berdasarkan indikasi gap atas hasil-hasil studi terdahulu itu, maka studi saat ini bertujuan mengkonfirmasi pengaruh dari financial leverage terhadap profitabilitas.

Berdasarkan alur pemikiran yang telah diuraikan, rumusan masalah dalam studi ini adalah bagaimana pengaruh dari 
Muhammad Fuad, Oyami Sara, \& Muhammad Nur Daud, Pengaruh Perputaran Modal Kerja, Operating Leverage dan Financial Leverage terhadap Profitabilitas Perusahaan Sektor Retail di Bursa Efek Indonesia ketiga variabel independen tersebut profitabilitas perusahaan sektor retail di terhadap profitabilitas perusahaan sektor retail di BEI, baik secara parsial maupun BEI.

Data sekunder untuk studi ini simultan. Hasil yang diperoleh melalui studi ini diekspektasikan memberikan informasi bagi perusahaan-perusahaan sektor retail secara umum ataupun secara khusus yang terdaftar di BEI mengenai variabel-variabel yang mempengaruhi profitabilitas usaha sehingga mampu mendesain strategi bisnis yang lebih sesuai agar mampu bersaing maupun menjaga keberlanjutan usahanya. Hasil studi ini juga berguna sebagai referensi pendukung bagi para peneliti selanjutnya ataupun pihakpihak yang berkepentingan utamanya mengenai hubungan antara perputaran modal kerja, operating leverage dan financial leverage dengan profitabilitas usaha.

\section{METODE PENELITIAN}

Penelitian ini bersifat explanatory, yaitu bertujuan menganalisis hubungan atau pengaruh dari beberapa variabel bebas terhadap variabel terikat sehingga bisa diperoleh model yang menjadi sarana pemecahan masalah (Sugiyono, 2016; Indriantoro \& Supomo, 2014). Dalam studi ini dianalisis model pengaruh dari perputaran modal kerja, operating leverage dan financial leverage terhadap operating leverage dan financial leverage, sementara variabel terikat adalah 
profitabilitas dari perusahaan sektor retail yang terdaftar di BEI. Variabel perputaran modal kerja diukur menggunakan skala rasio berupa perbandingan antara penjualan bersih dan modal kerja (Jumingan, 2011; Kasmir, 2015; Kusumo \& Darmawan, 2018). Variabel operating leverage diukur menggunakan skala rasio berupa perbandingan antara perubahan EBIT dan perubahan penjualan (Syamsuddin, 2016; Sen \& Ranjan, 2018). Variabel financial leverage diukur menggunakan skala rasio berupa perbandingan antara perubahan EPS dan perubahan EBIT (Halim, 2015; Syamsuddin, 2016; Sen \& Renjen, 2018). Variabel profitabilitas diukur menggunakan skala rasio berupa Return on Assets (ROA) atau perbandingan antara perubahan EBIT dan perubahan penjualan (Kasmir, 2015; Brealey et al., 2011; Gumanti, 2017).

Metode analisis data studi ini menggunakan regresi linier berganda, yaitu analisis regresi atas dua atau lebih variabel bebas terhadap variabel terikat yang mana terdapat dalam model studi ini (Sekaran \& Bougie, 2013; Sugiyono, 2016). Model regresi berganda yang dikembangkan dalam studi ini adalah sebagai berikut:

$$
\mathrm{Y}=\alpha+\beta 1 \mathrm{X} 1+\beta 2 \mathrm{X} 2+\beta 3 \mathrm{X} 3+\mathrm{e}
$$

dimana Y adalah profitabilitas, $\mathrm{X} 1$ adalah perputaran modal kerja, X2 adalah operating leverage, X3 adalah financial leverage, dan $e$ adalah error (tingkat kesalahan).

Selain melakukan analisis regresi linier berganda, juga dilakukan uji signifikansi atas pengaruh dari variabelvariabel bebas terhadap variabel terikat, yaitu uji parsial (uji $t$ ) dan uji simultan (uji $F$ ). Kriteria yang digunakan baik untuk uji parsial maupun uji simultan adalah jika nilai Sig. lebih kecil dari 0,05 maka pengaruh dinyatakan bersifat signifikan, sementara jika nilai Sig. lebih besar dari 0,05 maka pengaruh dinyatakan bersifat tidak signifikan (Indriantoro \& Supomo, 2014; Sekaran \& Bougie, 2013). Pemeriksaan nilai koefisien determinasi juga dilakukan untuk mengetahui besaran kontribusi dari variabel-variabel bebas dalam menjelaskan perubahan yang terjadi atas variabel terikat (Sugiyono, 2016; Sekaran \& Bougie, 2013).

\section{HASIL DAN PEMBAHASAN}

Analisis Regresi Linier Berganda

Hasil pengolahan data menggunakan program SPSS for Windows versi 20 dirangkum dalam Tabel 1. Berdasarkan tabel tersebut maka bisa diformulasikan 
model regresi linier berganda sebagai $\mathrm{Y}=0,052+0,001 \mathrm{X} 1+0,000 \mathrm{X} 2+0,016 \mathrm{X} 3$ berikut:

Gambar 1. Hasil Regresi Linier Berganda dan Uji Parsial

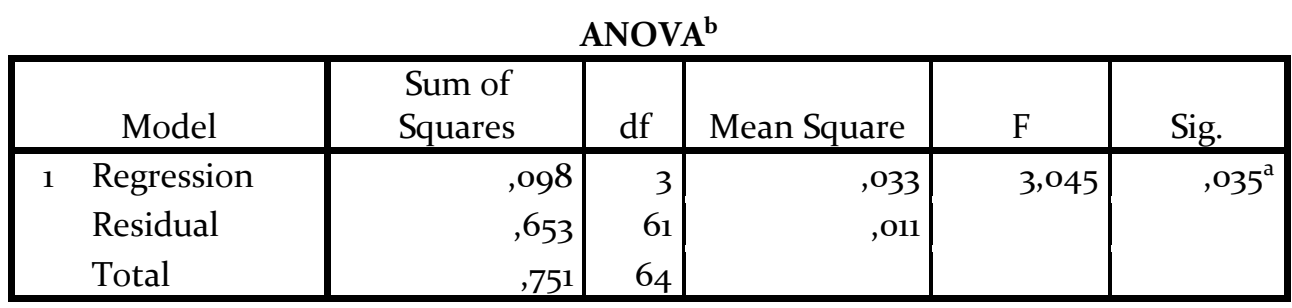

a. Predictors: (Constant), $\mathrm{X}_{3}, \mathrm{X}_{1}, \mathrm{X}_{2}$

b. Dependent Variable: Y

Sumber: Data sekunder diolah, Tahun 2018

Berdasarkan model regresi berganda itu diperoleh bahwa variabel-variabel bebas yaitu perputaran modal kerja $(\mathrm{X} 1=$ $0,001)$, operating leverage $(\mathrm{X} 2=0,000)$ dan financial leverage $(\mathrm{X} 3=0,016)$ memiliki arah pengaruh yang positif (searah) terhadap variabel terikat yaitu profitabilitas (Y). Dengan demikian, jika salah satu variabel bebas yang dianalisis tersebut mengalami peningkatan nilai maka nilai profitabilitas usaha juga akan mengalami kenaikan, atau sebaliknya jika variabel bebas tersebut mengalami penurunan maka nilai profitabilitas juga mengalami penurunan, dengan asumsi jika variabel-variabel bebas lainnya tidak mengalami perubahan. Lebih jauh, hasil perbandingan atas nilai koefisien regresi dari masing-masing variabel bebas yang dianalisis menunjukkan bahwa financial leverage (X3) memiliki pengaruh paling besar atau dominan terhadap profitabilitas (Y) perusahaan sektor retail di BEI.

\section{Uji Parsial (Uji $t$ )}

Untuk mengukur derajat signifikan atas pengaruh dari masing-masing variabel bebas terhadap variabel terikat, maka dilakukan uji parsial (uji t). Tabel 1 menunjukkan bahwa pengaruh dari dua variabel bebas yaitu perputaran modal kerja (X1, Sig. $t=0,382>0,05)$ dan operating leverage (X2, Sig. $t=0,247>0,05)$ terbukti tidak signifikan terhadap variabel terikat yaitu profitabilitas (Y). Sementara itu, pengaruh dari variabel financial leverage $(\mathrm{X} 3$, Sig. $t=0,017<0,05)$ terbukti bersifat signifikan atau berpengaruh secara nyata terhadap perubahan variabel profitabilitas (Y) perusahaan sektor retail di BEI.

\section{Uji Simultan (Uji $F$ )}

Berikutnya dilakukan pengujian derajat signifikan atas pengaruh secara simultan atau bersama-sama dari ketiga 
variabel bebas (X1, X2 dan X3) terhadap variabel terikat (Y). Hasil uji simultan (uji F) ditunjukkan dalam Tabel 2. Tabel tersebut menunjukkan bahwa pengaruh secara simultan dari ketiga variabel bebas yang dianalisis dalam studi ini terhadap variabel terikat (Sig. $F=0,035<0,05$ ) terbukti signifikan. Dengan demikian, ketiga variabel bebas dalam studi ini, yaitu perputaran modal kerja, operating leverage serta financial leverage, memiliki pengaruh secara simultan yang bersifat nyata terhadap perubahan profitabilitas perusahaan sektor retail di BEI.

Gambar 2. Hasil Uji Simultan

\begin{tabular}{|r|r|r|r|r|r|}
\hline \multicolumn{1}{|c|}{ Model } & $\begin{array}{c}\text { Sum of } \\
\text { Squares }\end{array}$ & Df & Mean Square & F & Sig. \\
\hline 1 Regression &, 098 & 3 &, 033 & 3,045 &, $035^{\mathbf{a}}$ \\
Residual &, 653 & 61 &, 011 & & \\
Total &, 751 & 64 & & & \\
\hline
\end{tabular}

a. Predictors: (Constant), $\mathrm{X}_{3}, \mathrm{X}_{1}, \mathrm{X}_{2}$

b. Dependent Variable: Y

Sumber: Data sekunder diolah, Tahun 2018

Gambar 3. Hasil Koefisien Determinasi

Model Summary

\begin{tabular}{|c|c|c|c|c|}
\hline Model & $\mathrm{R}$ & R Square & Adjusted R Square & $\begin{array}{l}\text { Std. Error of } \\
\text { the Estimate }\end{array}$ \\
\hline 1 &, $361^{a}$ & ,130 & ,o87 &, 10347 \\
\hline
\end{tabular}

a. Predictors: (Constant), $\mathrm{X}_{3}, \mathrm{X}_{1}, \mathrm{X}_{2}$

Sumber: Data sekunder diolah, Tahun 2018 


\section{Koefisien Determinasi}

Terakhir dilakukan analisis atas koefisien determinasi, yang bertujuan mengidentifikasi besaran kontribusi dari ketiga variabel bebas yang dianalisis pada studi ini dalam menjelaskan pergerakan atau perubahan yang terjadi atas profitabilitas perusahaan sektor retail di BEI. Hasil koefisien determinasi ditunjukkan dalam Tabel 3.

Tabel 3 menunjukkan bahwa nilai koefisien determinasi (R-Square) dari ketiga variabel bebas (X1, X2 dan X3) adalah 0,130 atau sebesar 13,0\%. Dengan kata lain, ketiga variabel bebas yang dianalisis memiliki kontribusi yang relatif kecil yaitu hanya sebesar 13,0 persen dalam menjelaskan perubahan-perubahan yang terjadi atas nilai profitabilitas perusahaan sektor retail di BEI. Sementara sisanya sebesar 87,0 persen menunjukkan bahwa masih terdapat sejumlah variabel bebas lainnya yang diduga juga mempengaruhi tren pergerakan dari profitabilitas usaha namun tidak tercakup dalam model yang digunakan pada studi ini. Berdasarkan hasil ini maka disarankan bagi para penelitian selanjutnya untuk mengidentifikasi sejumlah variabel independen lainnya yang dinilai bisa mempengaruhi pergerakan nilai profitabilitas perusahaan sektor retail yang terdaftar di BEI.

Berdasarkan hasil-hasil analisis yang telah dinyatakan, maka bisa dijabarkan tiga temuan penting dalam studi ini.

Temuan penting pertama adalah bahwa perputaran modal kerja memiliki pengaruh positif terhadap profitabilitas perusahaan sektor retail yang terdaftar di BEI. Hasil ini menunjukkan bahwa apabila pihak manajemen perusahaan retail itu mampu mempertinggi perputaran modal kerja maka nilai profitabilitas usaha juga akan mengalami kenaikan, atau sebaliknya jika perputaran modal kerja dalam bisnis mengalami penurunan maka nilai profitabilitas usaha juga mengalami penurunan; yang sesuai dengan argumen Pangestuti dan Oetomo (2016) serta Pais dan Gama (2015). Namun demikian, hasil uji parsial menyatakan pengaruh dari perputaran modal kerja terhadap profitabilitas bersifat tidak signifikan. Hasil studi ini karenanya memperluas temuan dari Kusumo dan Darmawan (2018), namun menyanggah milik Şamiloğlu dan Akgűn (2016) maupun Putri dan Sudiartha (2015). Dengan demikian, hasil ini menunjukkan bahwa untuk meningkatkan profitabilitas, manajemen perusahaan jangan berfokus pada percepatan perputaran modal kerja tetapi lebih pada 
optimalisasi penggunaan modal kerja dalam upaya menghasilkan peningkatan nilai laba bersih setelah pajak dengan memperhatikan margin of safety atas modal kerja tersebut. Upaya optimalisasi modal kerja bisa dilakukan pihak manajemen antara lain melalui kebijakan menginvestasikan dana yang dimiliki pada opsi-opsi sekuritas yang menguntungkan dan aman, manajemen piutang yang menyangkut jangka waktu tidak terlalu lama serta kemudahan penagihannya, serta manajemen persediaan yang tidak menyebabkan penumpukan barang dagangan di gudang namun tetap mampu memenuhi permintaan pasar.

Temuan penting kedua dalam studi ini adalah bahwa operating leverage berpengaruh secara positif terhadap profitabilitas perusahaan sektor retail yang terdaftar di BEI, yang berarti bahwa kenaikan nilai operating leverage yang dicapai pihak manajemen perusahaan akan menyebabkan kenaikan profitabilitas bisnisnya; atau sebaliknya jika nilai operating leverage menurun akan menyebabkan penurunan profitabilitas usaha. Sayangnya, hasil uji parsial menemukan bahwa nilai operating leverage berpengaruh secara tidak signifikan terhadap profitabilitas usaha. Hal ini berarti perubahan yang terjadi atas tingkat operating leverage tidak berpengaruh secara nyata terhadap profitabilitas usaha. Dengan demikian, hasil studi ini memperluas temuan empiris yang diperoleh Pangestuti dan Oetomo (2016) serta Sen dan Ranjan (2018), namun tidak mendukung temuan empiris milik Chen et al. (2017), Patel (2014) serta Lestari dan Nuzula (2017). Berdasarkan hasil ini, diperoleh bahwa peningkatan nilai EBIT terhadap total penjualan tidaklah berarti akan menghasilkan peningkatas atas tingkat profitabilitas usaha, dikarenakan adanya unsur operating costs yang bersifat mengurangi laba operasional. Profitabilitas dalam studi ini diukur menggunakan laba bersih setelah pajak (EAT), yaitu laba setelah dikurangi biaya-biaya operasional maupun umum plus bunga utang dan beban pajak. Semakin besar biaya operasional yang harus dipenuhi maka semakin kecil laba bersih setelah pajak yang bisa diperoleh perusahaan. Dengan demikian, pihak manajemen seharusya tidak hanya berfokus kebijakan pada strategi meningkatkan penjualan ataupun melakukan efisiensi atas bentuk-bentuk pengeluaran operasional yang selanjutnya akan mempertinggi laba operasional atau EBIT yang diperoleh, karena diidentifikasi tidak secara signifikan mempengaruhi peningkatan profitabilitas bisnis. Pihak 
Muhammad Fuad, Oyami Sara, \& Muhammad Nur Daud, Pengaruh Perputaran Modal Kerja, Operating Leverage dan Financial Leverage terhadap Profitabilitas Perusahaan Sektor Retail di Bursa Efek Indonesia

manajemen juga seharusnya mempertimbangkan hal-hal diluar aktivitas operasional seperti kebijakan efisiensi atas biaya-biaya administrasi dan umum (pengeluaran air, listrik, pulsa telepon atau ATK), ataupun pertimbangan efektivitas penggunaan utang terkait beban bunga serta depresiasi. Dengan mempertimbangkan semua bentuk beban yang harus dipenuhi, baik bersifat operasional maupun non-operasional, maka perusahaan bisa menyusun strategi peningkatan profitabilitas bisnisnya.

Temuan penting terakhir bahwa financial leverage berpengaruh secara positif terhadap profitabilitas perusahaan sektor retail yang terdaftar di BEI, yang berarti bahwa kenaikan nilai financial leverage yang dicapai pihak manajemen perusahaan akan menyebabkan kenaikan profitabilitas bisnisnya; atau sebaliknya jika nilai financial leverage menurun akan menyebabkan penurunan profitabilitas usaha. Hasil perbandingan koefisien regresi antara ketiga variabel independen dalam studi ini menunjukkan financial leverage memiliki pengaruh paling besar terhadap profitabilitas, yang berarti merupakan variabel yang seharusnya menjadi prioritas dalam strategi perusahaan untuk mampu mencapai tingkat profitabilitas yang lebih tinggi. Temuan uji parsial menemukan juga bahwa nilai financial leverage berpengaruh secara signifikan terhadap profitabilitas usaha, yang berarti perubahan yang terjadi atas tingkat financial leverage akan berpengaruh secara nyata terhadap profitabilitas. Dengan demikian, hasil studi ini memperluas temuan empiris yang diperoleh Lestari dan Nuzula (2017), Avistasari et al. (2016) serta Sen dan Ranjan (2018), namun tidak mendukung temuan empiris milik Ahmad et al. (2015), Patel (2014) serta Adongo (2012). Lebih jauh, temuan ketiga memperkuat rekomendasi yang diajukan dalam simpulan kedua, yaitu bahwa pihak manajemen harus memperhitungkan semua kewajiban baik bersifat operasional maupun tetap yang harus dikeluarkan perusahaan, termasuk bunga atas hutang dan dividen untuk saham preferen, dalam mendesain strategi pencapaian profitabilitas yang tinggi. Dengan memperhitungkan semua kewajiban yang harus dipenuhi tersebut, berarti pihak manajemen telah memandang seluruh aktivitas bisnis dari perusahaan yang dikelolanya.

\section{SIMPULAN}

Simpulan penelitian ini adalah bahwa secara parsial, perputaran modal kerja dn operating leverage terbukti memiliki pengaruh yang positif tetapi tidak signifikan terhadap profitabilitas; 
sementara financial leverage terbukti memiliki pengaruh positif dan signifikan terhadap profitabilitas dari perusahaan sektor retail yang terdaftar di BEI. Hasil ini menyatakan bahwa pihak manajemen perlu memprioritaskan financial leverage yang memiliki pengaruh parsial terhadap perubahan yang terjadi atas profitabilitas perusahaan yang dikelola. Secara simultan, pengaruh dari perputaran modal kerja, operating leverage dan financial leverage bersifat signifikan terhadap profitabilitas; yang berarti pihak manajemen harus mampu mendesain strategi yang secara tepat mengkombinasikan ketiga faktor tersebut karena akan berdampak positif bagi pencapaian nilai profitabilitas yang tinggi bagi perusahaan sektor retail yang terdaftar di BEI.

\section{DAFTAR PUSTAKA}

Adongo, J. (2012). The Effect of Financial Leverage on Profitability and Risk of Firms Listed at the Nairobi Securities Exchange. Thesis. Nairobi: MBA School of Business, University of Nairobi.

Ahmad, N., Salman, A. \& Shamsi, A.F. (2015). Impact of Financial Leverage on Firms' Profitability: An Investigation from Cement Sector of Pakistan. Research Journal of Finance and Accounting. 6 (7): 75-80.

Akbas, F.; Jiang, C. \& Koch, P.D. (2017). The Trend in Firm Profitability and the Cross-Section of Stock Returns. The Accounting Review. 92 (5): 1-32.

Alma, B. (2013). Manajemen Pemasaran dan Pemasaran Jasa. Bandung: Alfabeta.
Avistasari, F.K.; Topowijono \& Zahroh Z.A. (2016). Pengaruh Financial Leverage terhadap Profitabilitas Perusahaan (Studi pada Perusahaan Manufaktur Sektor Aneka Industri Sub Sektor Otomotif dan Komponen yang terdaftar di BEI Periode 2012-2014). Jurnal Administrasi Bisnis. 32 (1): 98-105.

Berman, B. dan Evans, J.R. (2010). Retail Management: A Strategic Approach. $11^{\text {th }}$ Edition. Upper-Saddle River, New Jersey: Pearson Education, Inc.

Brealey, R.A., Myers, S.C. dan Allen, F. (2011). Principles of Corporate Finance. $10^{\text {th }}$ Edition. New York, NY: McGraw-Hill/Irwin.

Brigham, E.F. dan Daves, P.R. (2016). Intermediate Financial Management. $12^{\text {th }}$ Edition. Singapore: Cengage Learning Asia Pte. Ltd.

Chen, Z.; Harford, J. dan Kamara, A. (2017). Operating Leverage, Profitability and Capital Structure. Working Paper. CICF 2013 Shanghai, China; EFA 2013, Cambridge UK; 24th CFEA (Kenan-Flagler Business School). Available at SSRN: https://ssrn.com/abstract $=2209070$ or http://dx.doi.org/10.2139/ssrn.2209070.

Fahmi, I, (2015). Analisis Laporan Keuangan. Bandung: Alfabeta.

Fuad, M. \& Wandari, A. (2018). Pengaruh Struktur Modal dan Faktor Eksternal terhadap Nilai Perusahaan (Studi pada PT. Bank Central Asia, Tbk.). Jurnal Manajemen dan Keuangan. 7 (1): 32-46.

Gumanti, T.A. (2017). Keuangan Korporat: Tinjauan Teori dan Bukti Empiris. Jakarta: Mitra Wacana Media.

Hamdani, T. (2019). Merasa Tak Adil, Pengusaha Ritel Minta Toko Online Diatur Ketat. DetikFinance. Edisi 16 Januari 2019. https://finance.detik.com/berita-ekonomibisnis/d-4387526/merasa-tak-adilpengusaha-ritel-minta-toko-online-diaturketat. Diunduh 21 Januari 2019.

Husnan, S. \& Pudjiastuti, E. (2012). Dasar-Dasar Manajemen Keuangan. Edisi Keenam. Yogyakarta: UPP STIM YPKN.

Indriantoro, N. \& Supomo, B. (2014). Metodologi Penelitian Bisnis: Untuk Akuntansi \& Manajemen. Edisi Pertama. Yogyakarta: BPFE.

Jumingan. (2011). Analisis Laporan Keuangan. Jakarta: PT. Bumi Aksara.

Kasmir. (2015). Analisis Laporan Keuangan. Jakarta: PT. RajaGrafindo Persada.

Kusumo, C.Y. \& Darmawan, A. (2018). Pengaruh Perputaran Modal Kerja, Ukuran Perusahaan dan Diversifikasi terhadap Profitabilitas (Studi pada Perusahaan Food and Beverage 
yang Terdaftar di BEI Periode 2013-2016). Jurnal Administrasi Bisnis. 57 (1): 83-89.

Lestari, Y.A. dan Nuzula, N.F. (2017). Analisis Pengaruh Financial Leverage dan Operating Leverage terhadap Profitabilitas Perusahaan (Studi pada Perusahaan Sektor Keuangan yang Terdaftar di Bursa Efek Indonesia Periode 2012-2015). Jurnal Administrasi Bisnis. 46 (1): 1-10.

Pais, M.A. dan Gama, P.M. (2015) Working Capital Management and SMEs Profitability: Portuguese Evidence. International Journal of Managerial Finance. 11 (3): 341-358.

Pangestuti, C.D.A. dan Oetomo, H.W. (2016). Pengaruh Perputaran Modal Kerja, Ukuran Perusahaan, Operating Leverage dan Financial Leverge terhadap Profitabilitas. Jurnal Ilmu \& Riset Manajemen. 5 (7): Juli.

Patel, J.B. (2014). Impact of Leverage on Profitability: A Study of Sabar Dairy. RESEARCH HUB - International Multidiciplinary Research Journal. 1 (3): October.

Putri, P.I.G. \& Sudiartha, G.M. (2015). Pengaruh Modal Kerja terhadap Profitabilitas Perusahaan Food and Beverages. E-Jurnal Manajemen Universitas Udayana. 4 (2): Februari.

Reily, M. (2019). Pengusaha Retail Tutup Gerai karena Faktor Lokasi dan Kondisi Ekonomi. Katadata.co.id. Edisi tanggal 16 Januari 2019. https://katadata.co.id/berita/2019/01/16/ pengusaha-retail-tutup-gerai-karena-faktorlokasi-dan-kondisi-ekonomi. Diunduh tanggal 21 Januari 2019.

Şamiloğlu, F. \& Akgűn, A.İ. (2016). The Relationship between Working Capital Management and Profitability: Evidence from Turkey. Business and Economics Research Journal. 7 (2): 1-14.

Sartono, A. (2008). Manajemen Keuangan: Teori dan Aplikasi. Edisi Keempat. Yogyakarta: BPFE.

Sekaran, U. dan Bougie, R.J. 2013. Research Methods for Business: A Skill-Building Approach. Sixth Edition. New York: Wiley.

Sen, G. dan Ranjan, R. (2018). Rapport between Leverage and Profitability: A Study of TVS Motor Company. Journal of Finance and Accounting. 6 (2): 49-55.

Sopiah \& Syihabudin. (2008). Manajemen Bisnis Retail. Jakarta: Andi Offset.

Sugianto, D. (2017). Ini Jajaran Ritel yang Tutup Toko di Indonesia. DetikFinance. Edisi tanggal $21 \quad$ November 2017. https://finance.detik.com/berita-ekonomibisnis/d-3736180/ini-jajaran-ritel-yangtutup-toko-di-indonesia/7, Diunduh tanggal 21 Januari 2019.

Sugiyono. (2016). Metode Penelitian Kuantitatif, Kualitatif, dan R\&D. Jakarta: Alfabeta.
Syamsuddin, L. (2016). Manajemen Keuangan Perusahaan: Konsep Aplikasi dalam Perencanaan, Pengawasan dan Pengambilan Keputusan. Jakarta: PT. RajaGrafindo Persada.

Zaking, S. (2019). Banyak Peritel Tutup Toko, Karena Ekonomi Lesu? DetikFinance. Edisi 16 Januari 2019. https://finance.detik.com/berita-ekonomibisnis/d-4386772/banvak-peritel-tutuptoko-karena-ekonomi-lesu. Diunduh tanggal 21 Januari 2019. 